Ardoin, P. J. and Parsons, B. M. (2007) Partisan Bias in the Electoral College: Cheap States and Wasted Votes, Politics \& Policy, 35(2): 342-364. (June 2007) Published by Blackwell Publishing (ISSN: 1747-1346).

DOI: $10.1111 / \mathrm{j} .1747-1346.2007 .00063 . \mathrm{x}$

\title{
Partisan Bias in the Electoral College: Cheap States and Wasted Votes[1]
}

Phillip J. Ardoin, Bryan M. Parsons

\begin{abstract}
This article dissects the sources of partisan bias in the institutional structure of the U.S. electoral college. Conventional wisdom and results of recent presidential elections suggest that the electoral college is biased in favor of the Republican Party. While previous empirical studies have challenged this conventional wisdom, George Bush's 2000 electoral college victory revived this debate. Our research provides a direct analysis of the multiple sources of bias within the electoral college and examines their individual impact on each party's electoral fortunes over the last eleven elections (1964-2004) with particular attention on the 2000 and 2004 presidential elections. Our results are in line with previous analyses indicating no significant bias within the electoral college. We conclude that parties and their presidential candidates are rational political actors who utilize sophisticated campaign strategies which allow them to efficiently employ their resources and limit any institutional disadvantages they may face.
\end{abstract}


The purpose of this research is to examine the sources of partisan bias in the institutional structure of the U.S. electoral college by dissecting the various sources of bias and directly examining their individual impact on presidential elections over the last four decades. While numerous scholars have examined bias in the U.S. House of Representatives (Brady and Grofman 1991; Campagna and Grofman 1990; Campbell 1995, 1996; Grofman 1983; King and Browning 1987; Niemi and Fett 1986; Tufte 1973), only a few have systematically examined bias in the electoral college (Berthoud 1997; Brunell and Grofman 1997; Destler 1996; Garand and Parent 1991; Gelman and King 1994; Gelman, Katz, and King 2004; Johnston, Rossiter, and Pattie 2005). Moreover, previous analyses of electoral college bias fail to directly address the most recent results of the 2000 and 2004 presidential elections which were substantially influenced by the distribution of electoral college votes.

Conventional wisdom among many journalists, political strategists, and even political scientists is that the electoral college is significantly biased in favor of the Republican Party and consequently provides the Republican Party with a "lock" on the electoral college.[2] While empirical research by Garand and Parent (1991), Destler (1996), Grofman, Brunell, and Campagna (1997), and Gelman and King (1994) have challenged this view, George Bush's electoral college victory in $\mathbf{2 0 0 0}$ with less than 50 percent of the two-party vote has revived the issue. To provide some clarity to the continuing debate, our research provides a direct analysis of the various sources of partisan bias (malapportionment, turnout differences, and geographic distribution of party vote shares) within the electoral college and examines their individual impact on the Democratic and Republican Parties' electoral fortunes over the last eleven elections. Finally, a detailed analysis of the 2000 and 2004 presidential election is presented in hopes of providing an improved understanding of the specific factors which contributed to George W. Bush's electoral college victory in 2000 despite his failure to receive a plurality of the popular vote.

\section{AMERICAN ELECTORAL INSTITUTIONS}

The role of American political institutions, their organizational structure, and the various outcomes they produce have been some of the most debated and divisive elements in American politics over the past several decades. The concept of institutional structure is one that crosses many disciplines, as well as various fields and subfields of political science. Not only have the causes of institutional organization and structure been of scholarly interest, but arguably greater scholarly emphasis has also been placed on examining various institutions in order to understand their effects on the political environment in which they function. For example, the most widely studied element of American political institutions is the legislative process, typically with greater emphasis on the U.S. Congress. It is not hard to understand why the legislative process has garnered such attention, which is most likely because of the degree of complexity and detail with which it operates as well as the various outcomes it generates.

American electoral institutions are also of great interest to political scholars. The two most significant and unique elements of our electoral institutions are the winner-take-all system of choosing governmental representatives and the electoral college through which we select 
presidents. The manner in which the winner-take-all system of elections interacts with the electoral college creates an interesting electoral dynamic that has led some scholars to speculate about potential biases inherent in the electoral college. In this article, we focus on examining the legitimacy of conventional wisdom which suggests that the electoral college has institutional mechanisms that create biased electoral outcomes.

Before addressing the details of the theory of institutional bias we posit in this article, it is appropriate to acknowledge the two methods by which the structure and organization of institutions-specifically the electoral college-are typically studied. First, examining the role of political actors in utilizing various aspects of a given institution for the purpose of manipulating outcomes is important to understanding how the structure of institutions allows for strategic behavior of actors. Many scholars have examined the various roles of political actors and the different ways in which they interact with the electoral college. Such areas as candidate campaign and travel strategies (Althaus, Nardulli, and Shaw 2002; Reeves, Chen, and Nagano 2004; Shaw 1999), candidate resource allocations to important states (Colantoni, Levesque, and Ordeshook 1975), micro/macro level citizen voting patterns (Jackson and Carsey 1999; Nardulli 1994), as well as examining how the strategic role of states and their interactions with variations in citizen voting power (Rabinowitz and MacDonald 1986) have been examined. It is quite plausible that the reason we observe seemingly biased outcomes in the electoral college (i.e., in the 2000 election) is because of the way various political actors (specifically candidates) utilize different elements of the institution to maximize benefits. While examining the roles of political actors and institutional outcomes is a plausible method of examining bias in the electoral college and could potentially be the focus of an expanded research project, we attempt to take a more general approach by focusing on the second conventional method of studying institutions. The focus of this article is on how the structure and organization of a given institution, in this case the electoral college, influences various electoral outcomes.

The way we structure our theory of partisan bias in the electoral college is by addressing the puzzle: are there institutional and electoral components of the electoral college that, ceteris paribus, create a consistent bias toward a particular party? Recent scholars have attempted to address similar puzzles in various ways. Employing methods from Gelman and King (1994) regarding the evaluation of electoral bias in congressional elections, Gelman, Katz, and King (2004) address bias in the electoral college. Their two primary mechanisms for bias are a particular party's/candidate's average vote share and its interaction with the probability of securing a majority of electoral votes, as well as the degree of voting power possessed by citizens of various states (see also Rabinowitz and MacDonald 1986) and potential electoral institutions (popular vote, congressional district vote, and others). Although Gelman, Katz, and King (2004) did not find evidence of systematic bias in the electoral college of the past several decades, conflicting evidence from other scholars suggests a different story. Johnston, Rossiter, and Pattie (2005), for example, address the issue of bias by examining several factors that they expect would interact to produce bias in the electoral college on a more conditional basis, rather than in any systemic sense. They hypothesize that institutional bias in the electoral college is a conditional function of two primary interacting factors: characteristics of a jurisdictional electorate (population size, voter turnout, and others), and the distribution of vote efficiency (wasted, efficient, or surplus votes). Their major findings are that institutional bias favored 
George Bush in 2000 (as a function of small state advantage, low turnout, and efficient votes), but favored John Kerry in 2004, albeit not as successfully.

While recent scholars have addressed issues of bias in the electoral college, we argue that the direct sources of partisan bias have yet to be clearly examined in a systematic fashion. Moreover, identifying the difference between partisan bias and swing ratio is a significant element in understanding party/candidate vote shares and should be clarified when examining institutional/electoral bias. The first reason why the theory of partisan bias posited in this article is important is because of the fact that it differentiates partisan bias from swing ratio. The confusion between the two concepts is inherent in much of the previous work on institutional bias in the electoral college. By clarifying these two concepts, which will follow in the next section, and identifying their consequences, we can better understand the characteristics of partisan bias in the institution of the electoral college. Second, this work attempts to expand the concept of vote efficiency (see Johnston, Rossiter, and Pattie 2005) in order to explain how partisan bias has been and can be largely driven by either party systematically utilizing wasteful and/or efficient votes. Finally, it is important to continuously reevaluate existing theories of institutional and electoral bias in large part because the scope of American political elections, institutions, and the public are continuously evolving elements of our political system. Any advances in the examination of systematic or conditional partiality present in our electoral institutions can aid our understanding of the ways in which the structure of political institutions can have substantial influence on various outcomes.

\section{ELECTORAL COLLEGE BIAS}

While the vast majority of research regarding partisan bias has focused on bias within the House of Representatives, a small number of scholars have examined the issue with regard to the electoral college. Borrowing liberally from the work of King and Browning (1987), the initial research on this topic was conducted by Garand and Parent (1991), who developed measures of representational form and partisan bias in the relationship between popular vote proportions and electoral vote proportions for each presidential election from 1872 to 1988. To the surprise of many observers of the presidential election process, the results of their analysis indicated that the electoral college was actually slightly biased in favor of the Democratic Party. Questioning the methods of Garand and Parent (1991), the research team of Grofman, Brunell, and Campagna (1997) reexamined the influence of partisan bias in the electoral college. Employing a hypothetical method of analysis, Grofman, Brunell, and Campagna's findings indicated that while partisan bias favored the Republican Party from 1900 to 1940, there has been no significant partisan bias in recent elections.

While the original works of Garand and Parent (1991), Grofman, Brunell, and Campagna (1997), and the more recent research of Gelman, Katz, and King (2004) provide sophisticated analyse of bias in the electoral college over the last century, they fail to provide a direct analysis of the sources of bias. The purpose of this research is to fill this void in our understanding of the electoral college system by examining directly each of the sources of bias and dissecting their individual influences on contemporary presidential elections. 


\section{PLAN OF ANALYSES}

Before beginning our analysis, we first define partisan bias and discuss how it differs from the swing ratio. As noted by Grofman, Brunell and Campagna (1997), confusion between partisan bias and swing ratio has led to much of the confusion regarding electoral college bias. Second, we discuss in detail the sources of partisan bias, wasted votes, and the price paid per electoral college vote. Third, we examine whether either party has systematically suffered or benefited more than the other party from these sources of bias in their attempts to win electoral college votes. Finally, we provide a detailed analysis of the factors which led to George W. Bush's electoral college victory in 2000, despite his popular vote defeat, and his reelection in 2004.

\section{Partisan Bias versus Swing Ratio}

While much of the confusion over the issue of partisan bias has been on account of the use of improper measures, a large portion of the misunderstanding of bias in the electoral college is because of the confusion between partisan bias and swing ratio. In two-party democratic political contests, partisan bias and swing ratio are the two primary measures of the characteristics of the association between a party's vote share and its share of electoral college votes.

The swing ratio is a measure of the responsiveness of the electoral system to changes in the proportion of the vote each party receives. In general, the swing ratio is the expected electoral college vote increase for each percentage point increase in a party's share of the aggregate popular vote. The second measure of the association between a party's vote share and its share of electoral college votes is partisan bias, which represents the degree to which competing political parties receiving the same vote proportions receive identical proportions of electoral college votes. More specifically, an electoral institution characterized by partisan bias produces differential treatment for the advantaged and the disadvantaged party, with the former receiving a higher proportion of electoral college votes than the latter for any given proportion of popular votes. As King and Browning (1987) state in their analysis of congressional bias,

[p]artisan bias introduces asymmetry into the seats-votes relationship, resulting in an unfair partisan differential in the ability to win legislative seats: the advantaged party will be able to receive a larger number of seats for a fixed number of votes than will the disadvantaged party ... We express the absence of partisan bias as partisan symmetry. In general, this means that in an election where $X$ percent of the Democratic votes produces an allocation of $Y$ percent of the seats to the Democrats, then in another election under the same system $X$ percent of the Republican votes would yield the $Y$ percent Republican allocation of seats.

While an unbiased system yields identical electoral college votes for equivalent Republican and Democratic vote proportions, a biased system yields more votes for one party than the other. For example, if the Democratic Party receives 48 percent of the electoral college votes with 50 percent of the popular vote and the Republican Party receives 52 percent of the electoral 
college votes with 50 percent of the popular vote, the system has a 4 percent bias in favor of the Republican Party.

\section{Sources of Partisan Bias}

Two basic factors contribute to partisan bias in the electoral college. The first is a disparity in the vote costs between parties. This is on account of differences in the population and/or number of voters per electoral college vote, which varies as a result of turnout differences and malapportionment. The second factor is asymmetries in the distribution of wasted votes between the parties which may occur as a result of variation in the distribution of partisan voting strength across states. For instance, if either party consistently wins competitive states and/or the larger states, they will waste significantly fewer votes in the United States' winner-take-all election process.

Ultimately, the number of electoral college votes a party wins depends on three factors: (1) the number of votes it has available to spend; (2) the price the party pays in popular votes for each electoral college vote; and (3) the number of votes the party wastes. A party that wins states where the number of votes per electoral college vote is low and/or wins states by narrow margins will spend its votes most efficiently; and the more efficiently a party spends its votes, the more electoral college votes it will win.

\section{ANALYSES OF BIAS [3]}

\section{Vote Costs}

The "price" of electoral college votes varies significantly between states. As Article II, Section I of the Constitution mandates that electoral college votes are allocated "equal to the whole number of Senators and Representatives to which the State may be entitled in Congress," there is tremendous variation in the cost of electoral college votes. The fact that each state, no matter how small its population, is guaranteed by the U.S. Constitution at least one seat in the House of Representatives and two seats in the U.S. Senate, even the smallest states receive at least three electoral college votes. Consequently, the electoral college overrepresents the least populous states, and the cost of electoral college votes in smaller states is potentially much lower than the cost of votes in larger states. As noted previously, these differences in the cost of votes can provide a significant source of partisan bias when one party consistently wins a significant number of small states.

As one would expect, considering the Constitutional requirement of at least three electoral college votes to every state, smaller states have substantially fewer citizens per electoral college vote than larger states. As Table 1 clearly displays, the population per electoral college vote varies dramatically between the states. [4] For instance, the average population per electoral college vote in California $(522,023)$ over the last eleven elections is 3.73 times as large as the average population per electoral college vote in Wyoming $(139,976)$. 


\begin{tabular}{|c|c|c|c|c|c|}
\hline State & EC Pop Rank & $\begin{array}{l}\text { Population Per } \\
\text { EC Vote }\end{array}$ & $\begin{array}{l}\text { Electoral College } \\
\text { Votes } 2004\end{array}$ & $\begin{array}{l}\text { Republican Victories } \\
\text { 1964-2004 }\end{array}$ & $\begin{array}{l}\text { Democratic Victories } \\
1964-2004\end{array}$ \\
\hline Wyoming & 1 & 139,976 & 3 & 10 & 1 \\
\hline Alaska & 2 & 144,872 & 3 & 10 & 1 \\
\hline Vermont & 3 & 169,910 & 3 & 6 & 5 \\
\hline North Dakota & 4 & 202,514 & 3 & 10 & 1 \\
\hline Delaware & 5 & 205,047 & 3 & 5 & 6 \\
\hline South Dakota & 6 & 207,084 & 3 & 10 & 1 \\
\hline Montana & 7 & 219,436 & 3 & 9 & 2 \\
\hline Washington, DC & 8 & 230,087 & 3 & 0 & 11 \\
\hline Idaho & 9 & 234,287 & 4 & 10 & 1 \\
\hline New Hampshire & 10 & 231,913 & 4 & 7 & 4 \\
\hline Oregon & Median & 392,554 & 7 & 5 & 6 \\
\hline North Carolina & 41 & 455,697 & 13 & 9 & 2 \\
\hline Georgia & 42 & 462,043 & 12 & 7 & 3 \\
\hline New Jersey & 43 & 463,076 & 16 & 6 & 5 \\
\hline Ohio & 44 & 465,166 & 24 & 5 & 6 \\
\hline Michigan & 45 & 466,914 & 20 & 5 & 6 \\
\hline Pennsylvania & 46 & 472,624 & 26 & 4 & 7 \\
\hline Illinois & 47 & 475,070 & 24 & 6 & 5 \\
\hline New York & 48 & 487,859 & 38 & 3 & 8 \\
\hline Florida & 49 & 503,485 & 20 & 8 & 3 \\
\hline Texas & 50 & 512,194 & 28 & 8 & 3 \\
\hline California & 51 & 522,023 & 47 & 6 & 5 \\
\hline
\end{tabular}

Ultimately, these differences in the population per electoral college vote present the possibility for significant electoral bias. If either party has an electoral advantage in smaller states, they are more likely to spend their votes efficiently and enjoy an advantage in the competition for electoral college votes. With this in mind, we examine the average number of victories by each party's presidential candidate in the least expensive and most expensive states. When one examines the ten least expensive states, the results clearly suggest a bias in favor of the Republican Party. Of the eleven elections since 1964, Republicans have been victorious 70 
percent of the time in the ten least expensive states, compared to only 55 percent of the time in the most expensive states, and 61 percent of the time in the other states. However, when one examines the average population per electoral college vote between the two parties, the results indicate only a modest and statistically nonsignificant Republican Party advantage. Specifically, for the 1964-2004 elections, the states in which the Republican candidate was victorious had an average population of 365,039 individuals per electoral college vote compared to Democratic states which had an average population of 359,660 votes per electoral college vote. This represents a difference of only 5,379 or rather 1.4 percent of the average population per electoral college vote.

While state populations are used to determine the number of electoral college votes allocated to each state, the population per electoral college vote only provides an indirect measure of the cost of electoral college votes. As one would expect, turnout varies significantly from state-tostate and therefore provides the chance for additional variation in the cost of electoral college votes between states. The direct and accurate measure of the cost of electoral college votes can be determined more by calculating the average number of actual votes cast per electoral college vote in each state.

Table 2 presents the average number of votes cast per electoral college vote in the ten most and least expensive states between 1964 and 2004. [5] Once again, these results indicate substantial variation in the cost of electoral college votes between states. While the costs of an electoral college vote in Alaska averages only 33,230 votes, the average cost per electoral college vote in Massachusetts is 112,644 votes. The cost of an electoral college vote from Massachusetts is 3.4 times the cost of one from Alaska. Clearly, variation in the cost of electoral college votes provides a potentially significant source of partisan bias. 
Table 2. Top Ten Least Expensive and Most Expensive Electoral College Vote States 1964-2004 by Turnout

\begin{tabular}{lllll}
\hline State & $\begin{array}{l}\text { Cost } \\
\text { Rank }\end{array}$ & $\begin{array}{l}\text { Popular Votes } \\
\text { Per EC Vote }\end{array}$ & $\begin{array}{l}\text { Republican } \\
\text { Wins }\end{array}$ & $\begin{array}{l}\text { Democratic } \\
\text { Wins }\end{array}$ \\
Alaska & 1 & 33,230 & 10 & 1 \\
Wyoming & 2 & 36,226 & 10 & 1 \\
Vermont & 3 & 41,559 & 6 & 5 \\
Hawaii & 4 & 44,433 & 2 & 9 \\
Delaware & 5 & 46,419 & 5 & 6 \\
Nevada & 6 & 48,202 & 8 & 3 \\
South Dakota & 7 & 51,457 & 10 & 1 \\
North Dakota & 8 & 52,626 & 10 & 1 \\
Montana & 9 & 54,777 & 9 & 2 \\
Washington, DC & 10 & 55,707 & 0 & 11 \\
Georgia & Median & 85,583 & 7 & 3 \\
Wisconsin & 42 & 100,356 & 4 & 4 \\
Ohio & 43 & 100,416 & 7 & 8 \\
New York & 44 & 101,345 & 3 & 6 \\
California & 45 & 101,436 & 6 & 5 \\
Michigan & 46 & 103,992 & 5 & 5 \\
New Jersey & 47 & 104,730 & 6 & 3 \\
Illinois & 48 & 105,573 & 6 & 9 \\
Florida & 49 & 105,779 & 8 & 10 \\
Minnesota & 50 & 106,099 & 1 & 2 \\
Massachusetts & 51 & 112,644 & & \\
\hline
\end{tabular}

While Table 2 unmistakably indicates a disparity in the cost of electoral college votes among the states, once again, this will only produce partisan bias if the system consistently provides one party with a distinct and systematic electoral advantage. To examine this issue, we first report the number of times each party has been victorious in the least expensive and most expensive electoral college vote states. A review of this data parallels the analysis previously discussed, again supporting conventional wisdom and indicating that the Republican Party more consistently wins the least expensive states while the Democratic Party relies more heavily on the most expensive states for their support.

Although Table 2 provides a cursory view of the partisan differences in the cost of electoral college votes, it does not present the complete picture. The more telling and appropriate means of examining this factor is to compare the actual difference in the average cost per electoral college vote between the two parties. With this in mind, we have calculated the average cost that each party has paid per electoral college vote over the period of our analysis (1964-2004). When one examines the overall difference between the parties in costs, there is only a minimal and statistically nonsignificant difference in favor of the Republican Party. Republican candidates have paid an average of 78,643 votes per electoral college vote in comparison to Democrats who paid an average of 81,094 . This represents a difference of only 2,451 votes 
cast per electoral college, or rather 661,770 fewer votes to achieve the 270 electoral college votes required to win the presidential election.

\section{Wasted Votes}

The second factor contributing to partisan bias in the electoral college is asymmetries in the distribution of wasted votes between the parties which may occur as a result of variation in the distribution of partisan voting strength across states. By reason of the winner-take-all system employed by the vast majority of states (Maine and Nebraska are the exceptions), all votes above 50 percent +1 for a party's candidate can be considered wasted votes. In addition, because of the winner-take-all system, all votes cast in states where the party's presidential candidate is defeated are considered wasted votes.

In Table 3, we present the number of votes each party wasted in states where they were victorious over the period of our analysis. An initial examination of this data suggests that the Republican Party has wasted significantly more votes $(75,910,759)$ than the Democratic Party $(53,791,196)$ over the last eleven elections in states where they were victorious. However, upon further analysis, the data reveal that this difference is actually because of the greater number of Republican presidential victories over the period of our analysis. More specifically, the party receiving the greatest number of popular votes naturally wins a greater number of states and, as a result, wastes more votes than the losing party. 


\begin{tabular}{|c|c|c|c|c|}
\hline \multirow[b]{2}{*}{ Election Year } & \multicolumn{2}{|c|}{ Sum } & \multicolumn{2}{|c|}{ Two-Party Percent } \\
\hline & Democrat & Republican & Democrat $(\%)$ & Republican (\%) \\
\hline 1964 (LBJ) & $17,048,665$ & $1,097,287$ & 12.34 & 17.81 \\
\hline 1968 (Nixon) & $2,212,660$ & $2,838,636$ & 7.54 & 6.05 \\
\hline 1972 (Nixon) & 312,863 & $18,312,391$ & 16.34 & 14.31 \\
\hline 1976 (Carter) & $3,395,138$ & $1,712,168$ & 5.92 & 4.22 \\
\hline 1980 (Reagan) & 553,166 & $8,973,436$ & 7.88 & 8.51 \\
\hline 1984 (Reagan) & 155,160 & $17,033,050$ & 18.02 & 11.33 \\
\hline 1988 (Bush) & $1,154,052$ & $8,231,155$ & 6.09 & 7.14 \\
\hline 1992 (Clinton) & $7,317,348$ & $1,512,092$ & 6.47 & 4.86 \\
\hline 1996 (Clinton) & $9,791,131$ & $1,587,529$ & 8.70 & 4.83 \\
\hline 2000 (GW Bush) & $6,477,569$ & $5,937,671$ & 7.36 & 8.30 \\
\hline 2004 (GW Bush) & $5,373,444$ & $8,675,344$ & 6.48 & 9.04 \\
\hline Average Democrat wins & $9,388,071$ & $1,477,269$ & 8.36 & 7.93 \\
\hline Average Republican wins & $2,319,845$ & $10,000,240$ & 9.96 & 9.24 \\
\hline All years & $53,791,196$ & $75,910,759$ & 9.38 & 8.76 \\
\hline
\end{tabular}

A more appropriate means of examining the number of votes wasted by each party is to evaluate separately the average number of votes each party wastes in years that their candidates win and also lose the general election. In contrast to the analysis of the total number of votes, these more appropriate measures suggest only a slight bias in favor of the Republican Party. In comparing the average number of votes wasted by each party in years when they won the general election, we find that the Republican Party wasted an average of 612,170 more votes than the Democratic Party. However, comparing the average number of votes wasted by each party in years when they lost the general election, we find that the Democratic Party wasted more votes with an average of 842,576 more votes. Subtracting these two figures, we find that the Democratic Party has wasted more votes $(230,406)$ than the Republican Party. 
While all votes over 50 percent +1 can be considered wasted votes, all votes in states where a candidate receives less than 50 percent are also considered wasted votes. Consequently, if either party consistently loses competitive states, they will spend their votes less efficiently which, once again, may lead to partisan bias.

The number of votes and average percentage of votes wasted by each party in states where their candidate was defeated over the last eleven presidential elections are reported in Table 4. The results indicate that both parties consistently waste more votes in losing states in years when they lose the national popular vote. Moreover, this difference is quite substantial, with the losing party wasting 34 times as many votes as the winning party in 1984, 24 times as many votes in 1972, and 17 times as many votes in 1964. Consequently, as a result of losing more presidential elections, Democratic candidates have wasted a significantly greater number of votes in losing causes than Republican candidates over the 40-year period of our analysis. Although this suggests a significant bias toward the Republican Party, further analysis shows these results are primarily a consequence of the two landslide victories that the Republican Party enjoyed in 1972 and 1984. For the remaining five elections, in which the Republican Party received a smaller margin of victory, the difference in the number of wasted votes between the two parties is significantly smaller and actually favors the Democratic Party. Interestingly, when one compares the average percentage of votes wasted in losing causes between the two parties, there is practically no difference. Both parties, on average, receive about 38 percent of the vote in states where they lose. Ultimately, we find neither party is systematically disadvantaged by the number of votes which they waste in losing states. 


\begin{tabular}{|c|c|c|c|c|c|c|}
\hline \multirow[b]{2}{*}{ Presidential Year } & \multicolumn{2}{|c|}{ Sum of Votes } & \multicolumn{2}{|c|}{ Average Percent } & \multicolumn{2}{|c|}{$\mathrm{N}$} \\
\hline & Democratic & Republican & Democratic (\%) & Republican (\%) & Democrat & Republican \\
\hline 1964 (LBJ) & $1,415,718$ & $24,665,183$ & 32.1 & 37.5 & 45 & 6 \\
\hline 1968 (Nixon) & $16,376,224$ & $11,506,776$ & 38.3 & 39.1 & 17 & 34 \\
\hline 1972 (Nixon) & $27,710,216$ & $1,147,304$ & 34.9 & 33.4 & 2 & 49 \\
\hline 1976 (Carter) & $17,013,478$ & $20,422,147$ & 44.5 & 43.3 & 24 & 27 \\
\hline 1980 (Reagan) & $32,080,019$ & $2,850,698$ & 37.9 & 38.1 & 7 & 44 \\
\hline 1984 (Reagan) & $36,360,413$ & $1,061,612$ & 38.3 & 31.6 & 2 & 49 \\
\hline 1988 (Bush) & $31,685,734$ & $8,969,699$ & 42.3 & 43.3 & 11 & 40 \\
\hline 1992 (Clinton) & $11,240,323$ & $26,352,135$ & 35.4 & 34.8 & 33 & 18 \\
\hline 1996 (Clinton) & $10,905,562$ & $26,705,664$ & 40.5 & 36.7 & 32 & 19 \\
\hline 2000 (GW Bush) & $21,836,063$ & $22,682,407$ & 40.1 & 40.4 & 21 & 30 \\
\hline 2004 (GW Bush) & $26,099,985$ & $25,895,833$ & 39.5 & 41.9 & 20 & 31 \\
\hline Republican wins & $192,148,654$ & $74,114,329$ & 38.7 & 38.3 & 11 & 40 \\
\hline Democratic wins & $40,575,081$ & $98,145,129$ & 38.1 & 38.1 & 34 & 18 \\
\hline All years & $232,723,735$ & $172,259,458$ & 38.5 & 38.2 & 214 & 347 \\
\hline
\end{tabular}

\section{PARTISAN BIAS?}

Is the electoral college biased toward the Republican or Democratic Party? In line with the findings of Grofman, Brunell, and Campagna (1997) and Destler (1996), the results of our analyses also suggest an absence of any significant partisan bias within the contemporary electoral college. While it may appear that the Republican Party would enjoy an advantage in the electoral college because of consistently winning more of the cheap electoral college states, the top ten least expensive states only represent a total of 32 electoral college votes. The Democratic Party can overcome this advantage by simply winning any of the top ten most expensive states which each represent at least 41 electoral college votes. As noted previously, 
while the Republican Party has spent their votes more efficiently over the period of analysis, the difference between the two parties represents an average of only 2,451 popular votes per electoral college vote, which is not substantially or statistically significant. Regarding the second source of bias, wasted votes, the two parties are relatively even. The total number of wasted votes for the Democratic Party is significantly greater. However, our analyses indicate that this difference is by reason of their presidential candidates winning the popular vote less often and losing by landslides in 1972 and 1984.

\section{THE 2000 AND 2004 PRESIDENTIAL ELECTIONS}

The previous discussion and analyses substantiate the findings of previous research which found the electoral college to be generally unbiased. Nevertheless, one should still explain how George W. Bush attained an electoral college victory in the 2000 presidential election despite losing the popular vote. Clearly, the electoral college system did not treat the two parties equally in the 2000 presidential election. The following section provides a detailed analysis of the 2000 and 2004 presidential elections to examine George W. Bush's extraordinary victory in 2000 and whether or not the electoral advantages he enjoyed in his first election persisted in his 2004 reelection.

As noted previously, the two basic sources of bias in the electoral college are the price each party pays for electoral college votes and the number of votes each party wastes in states where they are victorious and states where they are defeated. Tables 5-8 display the least expensive and most expensive electoral college states in the 2000 and 2004 elections and the average number of votes each candidate paid per electoral college vote. At first glance, the data do not indicate that the Republican Party enjoyed the success it normally finds among smaller states in either the 2000 or 2004 presidential elections. In each election, it won only half of the ten least expensive states. However, among the most expensive states, the Republican Party won only three states in each election. More importantly, a comparison of the average number of votes cast for each party's electoral college votes suggests only a minimal difference favoring the Republican Party and George W. Bush in both the 2000 and 2004 elections. As Tables 7-8 display, the Republican Party spent 4,687 fewer votes per electoral college vote than the Democratic Party in 2000 and only 2,181 fewer votes per electoral college vote in 2004. As with our aggregate analysis, the difference in vote costs for both elections is not statistically or substantially significant. 
Table 5. Top Ten Cheapest and Most Expensive Electoral College Vote States 2000

\begin{tabular}{llll}
\hline State & Votes Per EC Vote & Cost Rank & Winning Candidate \\
Wyoming & 49,316 & 1 & Bush \\
Vermont & 49,674 & 2 & Gore \\
Hawaii & 51,322 & 3 & Gore \\
Alaska & 55,799 & 4 & Bush \\
New Mexico & 57,357 & 5 & Gore \\
North Dakota & 58,284 & 6 & Bush \\
Delaware & 60,023 & 7 & Gore \\
Rhode Island & 62,377 & 8 & Gore \\
South Dakota & 63,567 & 9 & Bush \\
West Virginia & 67,295 & 10 & Bush \\
Oregon & 102,906 & Median & Gore \\
Maryland & 114,401 & 42 & Gore \\
Florida & 116,512 & 43 & Bush \\
North Carolina & 116,512 & 44 & Bush \\
Minnesota & 116,827 & 45 & Gore \\
Illinois & 117,683 & 46 & Gore \\
Texas & 118,739 & 47 & Bush \\
New Jersey & 119,257 & 48 & Gore \\
Michigan & 120,579 & 49 & Gore \\
New York & 124,476 & 50 & Gore \\
Massachusetts & 134,707 & 51 & Gore \\
\hline
\end{tabular}


Table 6. Top Ten Cheapest and Most Expensive Electoral College Vote States 2004

\begin{tabular}{llll}
\hline State & Votes Per EC Vote & Cost Rank & Winning Candidate \\
Alaska & 50,625 & 1 & \\
Wyoming & 55,710 & 2 & Bush \\
Hawaii & 57,830 & 3 & Bush \\
Vermont & 61,207 & 4 & Kerry \\
Washington, DC & 61,292 & 5 & Kerry \\
Rhode Island & 61,852 & 6 & Kerry \\
North Dakota & 65,333 & 7 & Kerry \\
Delaware & 66,629 & 8 & Bush \\
New Mexico & 75,388 & 9 & Kerry \\
South Dakota & 77,515 & 10 & Bush \\
New Jersey & 120,864 & Median & Bush \\
Illinois & 136,491 & 42 & Kerry \\
Oklahoma & 137,094 & 43 & Kerry \\
Washington & 137,291 & 44 & Bush \\
Pennsylvania & 137,418 & 45 & Kerry \\
Ohio & 142,936 & 46 & Kerry \\
Minnesota & 144,362 & 47 & Bush \\
Michigan & 145,591 & 48 & Kerry \\
Florida & 146,506 & 49 & Kerry \\
Wisconsin & 148,894 & 50 & Bush \\
Massachusetts & 149,493 & 51 & Kerry \\
& & Kerry \\
\hline
\end{tabular}

Table 7. Cost of Electoral College Votes in the 2000 Presidential Election

\begin{tabular}{lcc}
\hline & $\begin{array}{c}\text { Democratic Electoral } \\
\text { College Vote Cost }\end{array}$ & $\begin{array}{l}\text { Republican Electoral } \\
\text { College Vote Cost }\end{array}$ \\
$\mathrm{N}$ & 21 & 30 \\
Minimum & 49,674 & 49,316 \\
Maximum & 134,707 & 118,739 \\
Mean & 96,848 & 92,161 \\
\hline
\end{tabular}


Table 8. Cost of Electoral College Votes in the 2004 Presidential Election

\begin{tabular}{lcc}
\hline & $\begin{array}{l}\text { Democratic Electoral } \\
\text { College Vote Cost }\end{array}$ & $\begin{array}{l}\text { Republican Electoral } \\
\text { College Vote Cost }\end{array}$ \\
$\mathrm{N}$ & 20 & 31 \\
Minimum & 57,830 & 50,625 \\
Maximum & 149,493 & 146,506 \\
Mean & 111,321 & 109,140 \\
\hline
\end{tabular}

Table 9. Wasted Votes in the 2000 Presidential Election

\begin{tabular}{llccc}
\hline & \multicolumn{2}{c}{ Democrats } & \multicolumn{2}{c}{ Republican } \\
& $\begin{array}{l}\text { Wasted } \\
\text { votes over } \\
50 \%+1\end{array}$ & $\begin{array}{l}\text { Wasted votes } \\
\text { in losing } \\
\text { states }\end{array}$ & $\begin{array}{l}\text { Wasted } \\
\text { votes over } \\
50 \%+1\end{array}$ & $\begin{array}{l}\text { Wasted votes } \\
\text { in losing } \\
\text { states }\end{array}$ \\
& 21 & 30 & 30 & 21 \\
$\mathrm{~N}$ & 308,456 & 727,869 & 197,922 & $1,080,115$ \\
Mean & $6,477,569$ & $21,836,063$ & $5,937,671$ & $22,682,407$ \\
Sum & $28,313,632$ & & $28,620,078$ \\
Total wasted & & & &
\end{tabular}

Table 10. Wasted Votes in 2000 Presidential Election

\begin{tabular}{|c|c|c|c|c|}
\hline & \multicolumn{2}{|c|}{ Democrats } & \multicolumn{2}{|c|}{ Republican } \\
\hline & $\begin{array}{l}\text { Wasted } \\
\text { votes over } \\
50 \%+1\end{array}$ & $\begin{array}{l}\text { Wasted votes } \\
\text { in losing } \\
\text { states }\end{array}$ & $\begin{array}{l}\text { Wasted } \\
\text { votes over } \\
50 \%+1\end{array}$ & $\begin{array}{l}\text { Wasted votes } \\
\text { in losing } \\
\text { states }\end{array}$ \\
\hline $\mathrm{N}$ & 20 & 31 & 31 & 20 \\
\hline Mean & 268,672 & 841,935 & 279,850 & $1,294,792$ \\
\hline Sum & $5,373,444$ & $26,099,985$ & $8,675,344$ & $25,895,833$ \\
\hline Total wasted & \multicolumn{2}{|c|}{$31,473,429$} & \multicolumn{2}{|c|}{$34,571,177$} \\
\hline
\end{tabular}

Wasted votes are also an important source of partisan bias and Tables 9-10 display the sum of votes each party wasted in states where they were victorious and in states where they were defeated in the 2000 and 2004 presidential elections. Unsurprisingly, the results are at odds with each other for the 2000 presidential election. While the Democratic Party wasted more votes in those states where Al Gore won, the Republican Party actually wasted more votes in states where George W. Bush was defeated. Nevertheless, a comparison of the total number of wasted votes indicates that the Republican Party actually wasted 306,446 more votes than the Democratic Party. Clearly, wasted votes do not explain George W. Bush's 2000 electoral 
college victory. Finally, a quick analysis of Bush's successful 2004 reelection indicates that the Republican Party once again wasted more votes in states where Bush won and in those states where he lost. Overall, the Republican Party in the 2004 presidential election wasted 3,097,748 votes in winning and losing causes.

Considering the findings of both our cheap votes and wasted votes analyses, we conclude that the Republican Party's advantage in the 2000 electoral college was primarily on account of their spending votes more efficiently by wining more of the least expensive states. While the Republican Party spent only 4,687 fewer votes per electoral college vote than the Democratic Party, this represents a total of $1,265,454$ votes when one multiplies it by the actual number of electoral college votes required to win the presidential election. Clearly, this represents a substantial number of votes which had a significant impact in such a close election. The second question we must answer is whether this was because of a systematic bias in favor of the Republican Party or rather the strategic decisions the Bush Presidential Campaign made during the 2000 election with regard to allocating their resources. While the results of the 2004 election suggests that the Bush Campaign again spent fewer votes per electoral college vote, it also indicates that they wasted a substantially greater number of votes which would have offset their efficiency in spending votes if the election had been any closer.

\section{CONCLUSION}

We believe that this research broadens the understanding of the issue of partisan bias in the electoral college by providing a fuller analysis of the institutional mechanisms of the electoral college. First, we clarify the various sources of potential bias in the electoral college (cheap votes and wasted votes). Second, we directly examine each of these sources of potential bias and do not find a significant advantage in favor of the Republican or Democratic Party, which supports the previous findings of Grofman, Brunell, and Campagna (1997) and Destler (1996). Third, we note that the erroneous perception of a Republican bias in the electoral college which persists is likely because of their advantage in smaller states (which contributed substantially to Bush's 2000 electoral college victory) and their popular vote success combined with the tendency of the winner-take-all system to artificially inflate the victorious candidate's electoral college margin.

While the potential for bias within the institution of the electoral college is clearly high, we find that neither party over the last half-century has been able to consistently take advantage of these potential advantages. We argue that this is likely because of the fact that presidential candidates and the parties they represent are rational political actors, who understand the opportunities and problems of the institutional structure under which they work. Through the use of sophisticated polling and the strategic allocation of campaign resources, each party is able to diminish the inherent inefficiencies that confront their candidate and party. This was most vividly displayed in the 2004 presidential campaigns with the amount of attention each campaign committed to swing states. The Democratic Party knows that it is unlikely to achieve an electoral victory in solidly Republican states such as Wyoming and North Dakota and the Republican Party recognizes that it is unlikely to achieve electoral success in solidly Democratic states such 
as California and Massachusetts, hence, neither party waste limited resources in these states (Althaus, Nardulli, and Shaw 2002; Reeves, Chen, and Nagano 2004; Shaw 1999). Ultimately, each party's presidential candidate expends their limited resources (time and money) rationally and as a result, the level of partisan bias in the electoral college is severely restricted.

\section{NOTES}

1 An earlier version of this manuscript was presented at the 2005 Meeting of the Midwest Political Science Association, Chicago, IL.

2 This view is likely the result of the Republican Party's general advantage among several small states (which the electoral college overrepresents) and the inflated electoral college victories of several Republican presidents. An example of this view is characterized by the comments of a Democratic consultant who stated prior to the 1992 presidential election. "It's the same map we've had to deal with for years-and the results haven't been good. You need all the breaks with a map like that..." (Destler 1996, 421).

3 Data for the 1964-2000 presidential elections were attained from Congressional Quarterly's series: America at the Polls (McGillivray 2001). Data for the 2004 presidential election were attained from "David Leip's Atlas of U.S. Presidential Elections" (Leip 2004). All data utilized for the reported analyses and tables with all state results are available at http://www1.appstate.edu/ ardoinpj/ElectoralCollege.html.

4 For a list of the population per Electoral College vote for all states, see the authors' webpage at http://www1.appstate.edu/ ardoinpj/ElectoralCollege.html.

5 For a list of the votes cast per EC vote for all states, see the authors' webpage at http://www1.appstate.edu/ ardoinpj/ElectoralCollege.html.

\section{REFERENCES}

Althaus, Scott, Peter F. Nardulli, and Daron R. Shaw. 2002. "Candidate Appearances in Presidential Elections. Political Communication 19 (1): 49-72.

Berthoud, John E. 1997. "The Electoral Lock Thesis: The Weighting Bias Component. PS: Political Science and Politics 30 (2): 189-93.

Brady, David W., and Bernard Grofman. 1991. "Sectional Differences in Partisan Bias and Electoral Responsiveness in U.S. House Elections, 1850-1980. British Journal of Political Science 27 (2): 134-5.

Brunell, Thomas L., and Bernard Grofman. 1997. "The 1992 and 1996 Presidential Elections: Whatever Happened to the Republican Electoral College Lock? Presidential Studies Quarterly 27 (2): 134-5. 
Campagna, Janet, and Bernard Grofman. 1990. "Party Control and Partisan Bias in 1980s Congressional Redistricting. Journal of Politics 52 (4): 1242-257.

Campbell, James E. 1995. "Electoral System Bias in the House of Representatives: The Partisan Consequences of District Turnout Variation." Paper presented at the 1995 Annual Meeting of the Southern Political Science Association, Tampa, Florida. November.

Campbell, James E. 1996. Cheap Seats: The Democratic Party's Advantage in U.S. House Elections. Parliaments and Legislatures Series. Columbus: Ohio State University Press.

Colantoni, Claude S., Terrence J. Levesque, and Peter C. Ordeshook. 1975. "Campaign Resource Allocations under the Electoral College. American Political Science Review 69 (1): 141-154.

Destler, I. M. 1996. "The Myth of the Electoral Lock. PS: Political Science and Politics 29 (3): 491-94.

Garand, James C., and T. Wayne Parent. 1991. "Representation, Swing, and Bias in U.S. Presidential Elections, 1872-1988. American Journal of Political Science 35 (4): 1011-31.

Gelman, Andrew, and Gary King. 1994. "A Unified Method of Evaluating Electoral Systems and Redistricting Plans. American Journal of Political Science 38 (2): 514-54.

Gelman, Andrew, Jonathan N. Katz, and Gary King. 2004. "Empirically Evaluating the Electoral College." In Rethinking the Vote: The Politics and Prospects of American Electoral Reform, edited by Ann N.Crigler, Marion R.Just, and Edward J.McCaffery. New York: Oxford University Press. 75-90.

Grofman, Bernard. 1983. "Measures of Bias and Proportionality in Seats-Votes Relationships. Political Methodology 9 (2): 295-327.

Grofman, Bernard, Thomas Brunell, and Janet Campagna. 1997. "Distinguishing Between the Effects of Swing Ratio and Bias on Outcomes in the U.S. Electoral College, 1900-1992. Electoral Studies 16 (4): 471-87.

Jackson, Robert A., and Thomas M. Carsey. 1999. "Presidential Voting Across the American States. American Politics Quarterly 27 (4): 379-402.

Johnston, Ron, David Rossiter, and Charles Pattie. 2005. "Disproportionality and Bias in US Presidential Elections: How Geography Helped Bush Defeat Gore But Couldn't Help Kerry Beat Bush. Political Geography 24 (8): 952-68.

King, Gary, and Robert X. Browning. 1987. "Democratic Representation and Partisan Bias in Congressional Elections. American Political Science Review 81 (4): 1251-273.

Leip, David. 2004. "David Leip's Atlas of U.S. Presidential Elections." Accessed on December 1, 2004. Available online at http://uselectionatlas.org/ 
McGillivray, Alice V. 2001. America at the Polls, 1960-2000 John F. Kennedy to George W. Bush: A Handbook of American Presidential Election Statistics. Washington, DC: Congressional Quarterly Press.

Nardulli, Peter F. 1994. "A Normal Vote Approach to Electoral Change: Presidential Elections, 1828-1984. Political Behavior 16 (4): 467-503.

Niemi, Richard G., and Patrick Fett. 1986. "The Swing Ratio: An Explanation and an Assessment. Legislative Studies Quarterly 11 (1): 75-90.

Rabinowitz, George, and Stuart Elaine MacDonald. 1986. "The Power of the States in U.S. Presidential Elections. The American Political Science Review 80 (1): 65-87.

Reeves, Andrew, Lanhee Chen, and Tiffany Nagano. 2004. "A Reassessment of 'The Methods Behind the Madness: Presidential Electoral College Strategies, 1988-1996.' Journal of Politics 66 (2): 616-20.

Shaw, Daron R. 1999. "The Methods behind the Madness: Presidential Electoral College Strategies. Journal of Politics 61 (4): 893-913.

Tufte, Edward R. 1973. "The Relationship between Seats and Votes in Two-Party Systems. American Political Science Review 67 (2): 540-54. 